\title{
Drivers of Customer Switching Behaviour in the Nigerian Road Transport Industry
}

\author{
Onyeagwara Chukwuemeka O. ${ }^{\text {a }}$, Chukwudi I. Njelita ${ }^{a}$, Agu Godswill Agu, ${ }^{\text {,** }}$ \\ ${ }^{a}$ Department of Marketing, Nnamdi Azikiwe University, Awka, Nigeria \\ ${ }^{b}$ Department of Marketing, Abia State University, Uturu, Nigeria
}

\begin{abstract}
The purpose of this study was to investigate the factors driving customer switching behaviour in the Nigerian road transport industry. Arguing from the theory of planned behaviour, a survey of 371 (306 valid) customers of the organized road transport industry in Nigeria's South-East was carried out. Collected data was analyzed with multiple regression analysis (MRA) in SPSS 21.0. Findings indicate that service quality, price, and promotion are positive and significant drivers of switching behaviour, while location is not. The study recommends crafting marketing strategies around service quality, price, and promotion as effective approach to avoid customer swapping.
\end{abstract}

Keywords: customer switching behaviour; Nigerian road transport industry

\section{Introduction}

Given the advent of modern competitive strategies in many sectors of the Nigerian economy, customer loyalty has remained fickle to the disadvantage of marketing firms who place more value on customer loyalty. The service sector globally and Nigeria in particular has witnessed series of Information and Communication Technology (ICT)-based innovations that tend to drive customers towards switching from one service provider to the other. As noted by Keaveney (1995), services marketers have recognized that "having customers, not merely acquiring customers is crucial for service firms". To retain customers, scholars have identified such factors as service quality, relationship quality as well as overall service satisfaction as drivers (Berry, 1980; Bitner,1990; Crosby, Evans \& Cowles, 1990; Cronin \& Taylor, 1990).

However, reviewed literature and observation have shown that in spite of the efforts of most service providers to ensure that they retain their customers, many service customers have reasons to switch from one service provider to the other (Chiu, Hsuh, Li \& Lee, 2005; Onyeagwara \& Agu, 2017). Brand switching has been defined as the process by which consumers switch from the usage of one product to another product of the same category (Kumar and Charles, 2011). According to Lyarder et al (1998) in Njoku, Nduka and Okocha (2015), although customers express their satisfaction or otherwise, they nevertheless frequently switch brands. As rightly observed by Gerard and Cunningham (2004), switching behaviour is mostly an outcome of multiple incidents, not just a single one.

Scholars have revealed the negative implication of customer switching on service firms' market share and profitability (Ahmed et al., 2015; Rust \& Zahorik, 1993; Keveney, 1995). They noted that switching costs the service firm the customer's future revenue stream, noting that the lost of a continuing service customer is a lost from the high-margin sector of the firm, because continuing customers increase their spending at an increasing rate, purchase at full-margin rather than discount prices and create operating efficiency for service firms (Reichheld \& Sasser, 1990). Again, there are costs that are associated with the acquisition of new customers (Peters, 1988; Agbonifoh et al., 2007; Ogwo \& Agu, 2015; Okpara, 2012). Among them is the psychological effect (negative signal) that a service firm suffers when its well known customers switch to other providers. This can create difficulties in attracting new customers to the affected firm.

\footnotetext{
* Corresponding author.

E-mail address: talk2godsag@yahoo.com
} 
Over the years, scholars have attempted to reveal and give insights into the switching behaviour of service customers. Series of studies have been conducted using the banking sector (Keveney, 1995; Chiu et al., 2005; Rust et al., 1993; Onyeagwara \& Agu, 2017), telecommunication sector (Liang, Ma \& Qi, 2013), Insurance (Crosby \& Stephen, 1987), among others. However, the industry specific nature of these studies necessarily limits the generalizability of their findings (Lovelock, 1983; Keveney, 1998). This makes it imperative for a separate study into a growing service industry in Nigeria, which has continued to be increasingly competitive in nature (Ogwo \& Agu, 2015; Agu, Madumere \& Uche, 2016; Agu, 2015).

The Nigerian road transport industry has been described as hyper-competitive since the entrance of organized operators in the industry (Ogwo et al., 2015). There are many categories of transporters, who engage in inter-city, long-distance and shuttle movements. According to Agu et al. (2016), there are roadside, open market operators, which are largely unorganized; there are the semi-organized and the organized operators. Again, some are owned by the government, while many are owned by private organizations. Although the demand for road transport services has remained high since over 75\% of the Nigerian population depends on road transport (Agu, 2015; Chidoka, 2009), operators have continued to strategize using modern customer oriented approaches to attract and retain customers as well as to avoid customer switching. According to Kotler (2003), customer retention may be strengthened by creating high switching costs using high customer satisfaction. He noted that customers should not just be satisfied, but they should be delighted.

It therefore follows from the foregoing, that the present day Nigerian road transport customers are in search of firms that will not only satisfy them, but also delight them. This is because a good number of users of the organized and semi-organized road transport services are those who also own their private vehicles, and understand the science of driving. Majority patronize the commercial transporters because of the decayed road infrastructure, phobia of longdistance driving and the availability of "reliable" commercial road transport services providers. A good number of these customers are well educated, economically stable and are ready to pay for the comfort and safety they demand (Agu, et al., 2016). This scenario makes switching from one provider to the other possible and reduces loyalty intentions. Most studies on the Nigerian road transport industry focused on preference and loyalty factors. There is no known study on customer switching behaviour in the industry. This study extends the literature on customer switching behaviour to capture the perceptions of road transport customers on drivers of switching intention. Specifically, the following objectives were explored:

(1) To measure the extent at which service quality drives switching behaviour among road transport customers in the South East, Nigeria.

(2) To ascertain the extent at which price drives switching behaviour among road transport customers in the South East, Nigeria.

(3) To measure the extent at which promotion drives switching behaviour among road transport customers in the South East, Nigeria.

(4) To measure the extent at which location drives switching behaviour among road transport customers in the South East, Nigeria.

\section{Literature Review}

\subsection{Concept of Customer Switching}

Customer switching has been defined by Keaveny and Parthasarathy (2001) as an act of being loyal to one product category, but switch from one service provider to another, as a result of dissatisfaction or any other related problems. Farlex (2016) sees it as "a Customer's act of buying a product different than one of the same kind that he/she previously purchased". Brand switching has been defined by Mouri (2005), Farlex (2016) Keaveny and Parthasarathy (2001) as the termination of customer relationship with particular service provider and continuation of relationship with a new service provider. Stewart (1994) defined customer switching behavior as defection or exit of customers from company. Customers can switch brands either on permanent basis or on temporary basis. Boote (1998) has defined customer switching behavior as decision of customers to discontinue purchase dealings permanently or temporary. Rajkumar (2011) defines brand as switching when customers switch their loyalties from one particular 
brand to another. These definitions suggest that brand switching occurs when customers stop purchasing a particular product and start purchasing another either on temporary basis or on permanent basis.

The factors that drive customer switching behaviour in the service industry as explored by Keveney (1995) and validated by Vyas and Raitani (2013) and Onyeagwara and Agu (2016) include service quality, reliability, assurance, tangibles, empathy, responsiveness, price, customer commitment, reputation, effective advertising competition, responses to service failure, customer satisfaction, involuntary switching, service products. Other drivers of switching behaviour have been identified by some other researchers. These include: Switching Cost (Grzybowski, 2004; Burnham, Frels and Mahajan (2003) and Trust (Chu, 2009; Serkan and Ozer (2005). However, this study focuses on the effect of service quality, price, promotion and location on the switching behaviour of road transport customers in the South East, Nigeria.

\subsection{Theoretical framework}

Many scholars in the field of marketing and other social sciences have identified different theories relating to customer switching behaviour. Such theories include: the Agency Theory (Ehab, Wael, \& Salah, 2008); the theory of planned behavior (Gall, \& Olsson, 2012) and the General Systems Theory ( Njite, Kim, \& Kim, 2008). However, for the purpose of the study, attention will be on the theory of planned behavior which, according to Ajzen (1991), extends the understanding of the consumer decision-making process by considering how the concepts of attitude, perceived behavioral control, subjective norms and intention influence specific behaviors, including purchasing decision.

The theory of planned behavior is an extension of the theory of reasoned action, suggested by Fishbein \& Ajzen (1975) as cited in Ajzen (1991). The theory of planned behavior was proposed by Ajzen (1985, cited in Ajzen, 1991), as a response to criticism against how the theory of reasoned actions failed to include behaviors which people have incomplete control of. Therefore, the concept of perceived behavioral control was added to the new model (Ajzen, 1991). Consequently, the theory of planned behavior consists of a framework showing how norms, attitudes and perceived behavior control influences planned and realized behavior (Ajzen, 1991).

According to Ajzen (1991) the attitude towards the behavior concerns the degree to which an individual possess a generally favorable or unfavorable evaluation of the specific behavior in question. Beliefs about a specific behavior are formed by associating it with certain attributes; that are either valued positively or negatively (Ajzen, 1991). The factor subjective norms relates to whether or not an individual is under strong social pressure (Ajzen, 1991). If the social pressure is strong the individual may need approval from important social peers to perform the given behavior, e.g. family and friends (Ajzen, 1991). Lastly, perceived behavioral control refers to whether an individual perceives it as easy or difficult to perform the specific behavior, i.e. whether the individual perceives to have sufficient control to perform the behavior (Ajzen, 1991).

\subsection{Service quality and customer switching intention}

The study of Liu (2015) explored the impacts among e-service quality, perceived value, e-satisfaction and e-trust, and switching intention in Internet trading systems of the securities industry. The object of this study was online traders who had used Internet trading systems of the securities industry in Taiwan. The collected data were analyzed by using statistical methods. The findings of this study indicate that there were significantly positive correlations among eservice quality, perceived value, e-satisfaction and e-trust, and all of which had a negative correlation with switching intention; e-service quality had a significantly positive and direct impact on perceived value and e-satisfaction, but there was no significantly positive impact on e-trust. E-service quality affected switching intention through two intervening variables as perceived value and e-satisfaction. These results also can provide insights into the effect on switching intention and thus offer improvable and strategic suggestions for the securities industry to provide better etrading systems to the investors.

The purpose of the study of Kumaradeepan (2012) was to find out why customers switch producers in telecommunication industry in Sri Lanka. The objective of this study is to find out how the variable service quality would lead to customers switching. Primary data were collected from the customers through well designed questionnaires. Also focus group discussion and some of interview taken placed to justify the findings. Targeted area was Jaffna district and sample size is 300 questionnaires. Interview and focus group discussion have taken place to 
find out the influences on purchasing. Collected data were analyzed by quantitative techniques and Ms excel sheet used for interpretation. It was found out that there was a negative relationship between Service quality and customer switching of producers. Also results expressed that agreed level of service quality would increase customer satisfaction and lead to less level of switching the same producer.

Chinwendu (2017) studied the impact of product quality on consumer brand loyalty. The main purpose was to find out the impact of product quality on consumer brand loyalty as generated high profit to intercontinental distiller limited products in Ota, Ogun state. Both primary and secondary data collection method were used in gathering information, books journal and past project were used. Questionnaires were administered and personal interview were conducted. The major findings were those consumers who are strictly concerned about product features. It was also find that product quality has great influence in consumer preference as promotional message with great precision to advertising brand loyalty. It was therefore recommended that quality level of the product yield great influence on consumer. It should therefore be strictly maintained and improved. They should also know every producer of products of any sort should pay great attention to most qualitative production with its ability.

Evelyn (2013) the study is on the effect of product quality on the consumer brand loyalty: a tool for achieving customer brand loyalty in the 7up bottling company Aba was conducted to investigate the extent of relationship between product quality and consumer brand loyalty in the 7up company. More so, to achieve the objectives of the study, a research design was used to study the company where 140 questionnaires were administered to the respondents in order tested using the chi-square SPSS formula, where the decision shows when the value of $\% x$ in SPSS is less than the alpha value of 0.05 and less than $\mathrm{x} 2$ value from the tables, we therefore, reject Ho and accept Ha that product quality increases the demand of a product. Based on the findings of this study, that the quality of a product affects consumers' loyalty, the following were recommended. That for an organization to maintain consumer loyalty, product quality lines. From the recommendations, the following suggestion for further studies were made that effort should be made to study the effect of quality in other product.

Shah, Husnain and Zubairshah (2018) carried out a study with the purpose investigating the factors effecting brand switching behavior of customers in telecommunication industry of Pakistan. A qualitative approach was employed to measure the relationships between the variables of the study. Primary data were collected through the use of in-depth interview technique; open-ended questionnaire is used while transcripts were analyzed drawing from sample of education department. NVivo 11 version was used to determine the relationship and to validate the study. The paper explored findings from a qualitative data through face-to-face interview about tendency of customers brand switching behavior towards telecommunication industry. The in-depth interviews revealed that quality of service, influence of family, friends \& relatives and price structure were among the determining factors that influence customers' satisfaction towards brand switching behaviour.

\subsection{Pricing and customer switching intention}

Grewal, Roggeveen, Compeau and Levy (2011) explained on pricing, which can be defined as a key central component of any marketing strategy of an overall business model. In terms of marketing pricing strategies, Biggs and Kelly (2006) had stated out that there are three main pricing strategies for the telecommunication industry such as flat-rate pricing, time-based pricing, volume-based pricing. For the flat-rate pricing from, consumers are needed to pay a fixed amount of the particular services regardless of the usage of the service. For the time-based pricing strategy from, it is depending on how long consumers spending time on online and then closed the account into the customers' due bill meanwhile volume-based pricing can be defined as customers pay the bill on how many data content downloaded from them.

As observed by Xavier and Ypsilanti (2008), price is the main character that can make impact on switching levels. Price switching can occur over a long-time period if pricing is not clear enough. Also, if the companies keep the high price in the market, they are not having and occurring competitive market. Lastly, certain activities such as mis-selling and marketing churning can be covered by high switching levels. Xavier et al. (2008) also explained that if there is a low switching level, it will not make any sense because the market will be competitive as usual. Limited switching may occur if the price has been dropped down to a competitive level. Price can be also defined as a factor that not only can be set by telecommunication industries but also related to control the diffusion process (Karine, Frank $\&$ Laine, 2004). According to Kollmann (2000), most of the private service providers have understood whom customers are willing to switch providers by deciding on the price of the services. Service providers who offer lower charges 
may attract more customers to purchase from them. H1: There is significant relationship between price and consumer switching behaviour in telecommunication industry.

\subsection{Promotion and customer switching intention}

Various theoretical and empirical works on switching behaviour recognized the significant impact of patterns of advertising viz. newspaper, magazine, radio and T.V. on brand selection (Cobb \& Hoyer, 1985). In this regard scholars have shed lights on the effectiveness of television advertisements in persuading consumers by creating differentiation among products and triggering cognitive efforts for making a brand choice (Deighton et al., 1994; Ackerberg, 2003 etc). Advertising in various media such as television, radio etc. along with the use experience has an effect on both utility mean and variance (Chakrabortty et al., 2013). Further components such as likability, expertise, trust worthiness and similarity cause a celebrity endorser to become a source of persuasive information and effectiveness of a message (Pradhan et al., 2014). Thus, consumers often switch to those brands as supported by their preferred celebrities (Bush et al., 2004). Therefore, a major reason for consumers' switching to other brands is the impact that advertisements generate into their minds (Erdem et al., 2008 and Srivastava \&Bisen, 2014).

Promotions through distributed coupons, cents-off deals inducements, different kinds of bonuses, price discounts, extra grammage, savorpacks and special displays influence brand switching greater than repeat purchases (Vilcassim \& Jain, 1991; Erdem et al., 2008 and Nagar, 2009). A sales person is often emphasised as a principal medium for communicating the consumers about the arrival of the new brands in the markets that can satisfy their needs. Thus, brand switching is often influenced through personal selling (Kim \& Huyan, 2011). Brand switching is also influenced by word of mouth publicity by others. Research study by East et al. (2008) has instituted that positive word of mouth is more influential than negative word of mouth in brand choice probability. Further, positive information about brands obtained through informal groups, family or others increases brand association, perception of quality and brand loyalty (Murtiasih et al., 2013).

\subsection{Location and customer switching intention}

Nyarko (2015) sought to determine the factors that influence the switching behaviour of customers of Ghana Commercial Bank, Limited in Ho. A descriptive, cross-sectional survey was conducted among 350 purposively selected individual customers. Logistic regression analysis was used to identify the predictors of switching intentions among customers. Results show that four factors; X1 (High transaction fee), X4 (Attractiveness of alternatives), X7 (Inconvenience of bank location) and X9 (Inability to respond to system failure quickly) were statistically significant in the prediction of customer switching with a predicted switching rate of $82.29 \%$. It is suggested there is a need for banks to review their bank charges or transaction fees in the banking sector since high transaction fees have an impact on customer switching behaviour. Also, management should establish more branches in the same township since customers switch in the inception of convenience in the services and location of the banks. Finally, banks should regularly update their system and also employed welled trained staff who will respond to system failure quickly. In addition, they should strive to provide the greatest possible customer satisfaction and convenience them so that they would have greater customer satisfaction than competitive banks.

\section{Research methodology}

In this study, the survey research design was adopted. The researcher utilized the interview, questionnaire and observation in this present study. 371 copies of the questionnaire were administered on customers of the eight road transport firms (ABC, Peace Mass, God is Good Motors ITC, Abia Line, ESTMASS, TRACAS, and EboMass) in the South East of Nigeria. Out of this number, 306 copies were retrieved and used. Again, the ontological research philosophy was adopted in this study since objective and subjective assessment of the perceptions of customers were studied. This study combined the objectivist and subjectivist views in attempting to unravel the vector influencing customer switching behavior in the transport industry. Secondary and primary data were used in this study.

Primary data collected with the uses of structured questionnaire were analyzed using tables, charts and simple percentages. On the other hand, stated hypotheses were tested using multiple regression analysis at 0.05 level of significance in SPSS version 21. 
The direct effect research model for this study is of the form:

\section{CSB $=\mathbf{f}($ SVQ, PRC, PRM, LCT $)$}

where:

CSB is Customer Switching Behaviour;

SVQ is Service Quality

PRC is Price;

PRM is Promotion

LCT is Location

In order to validate (accept) or nullify (reject) any stated hypothesis tested with the multiple regression, major attention was paid to the P- values of the tested constructs. Therefore, we rejected the null hypotheses where the SPSS p-values are less than alpha (0.05) and the alternative hypotheses accepted.

\section{Results and Discussions}

4.1. Data presentation and analysis

Table 1. Demographics of respondents

\begin{tabular}{lll}
\hline Categories & Frequency & Percentage \\
\hline Gender: & 117 & 38 \\
Male & 189 & 62 \\
Female & 113 & \\
\hline Age Bracket & 101 & 37.00 \\
$18-25$ & 57 & 33.00 \\
$26-35$ & 35 & 19.00 \\
$36-45$ & & 11.00 \\
46 years and above & 84 & 27.00 \\
\hline Academic Qualification & 177 & 58.00 \\
O'Level/ND & 30 & 10.00 \\
HND/B.Sc. & 15 & 05.00 \\
Masters and above & & \\
Others & 153 & 50.00 \\
\hline Marital Status & 126 & 41.00 \\
Single & 27 & 09.00 \\
Married & & \\
Others & & \\
\hline
\end{tabular}

Source: Field Survey, 2020

Information shown in table 1 is further presented in the following figures:

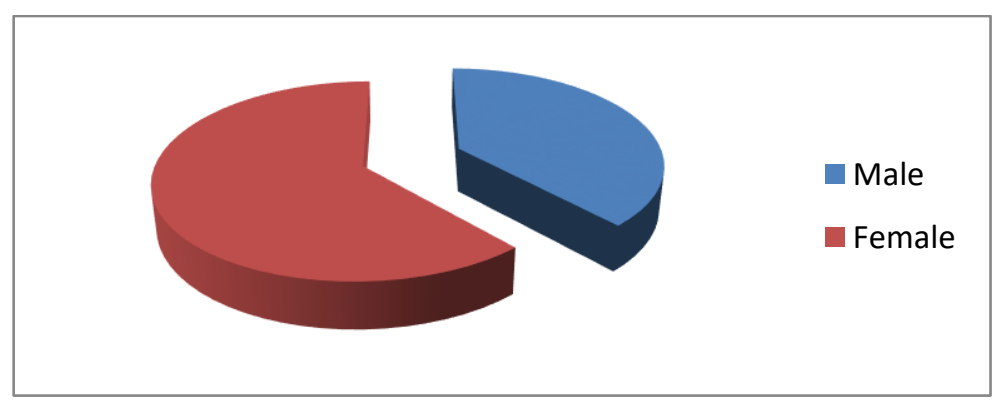

Figure 1. Pie Chart showing gender of respondents 


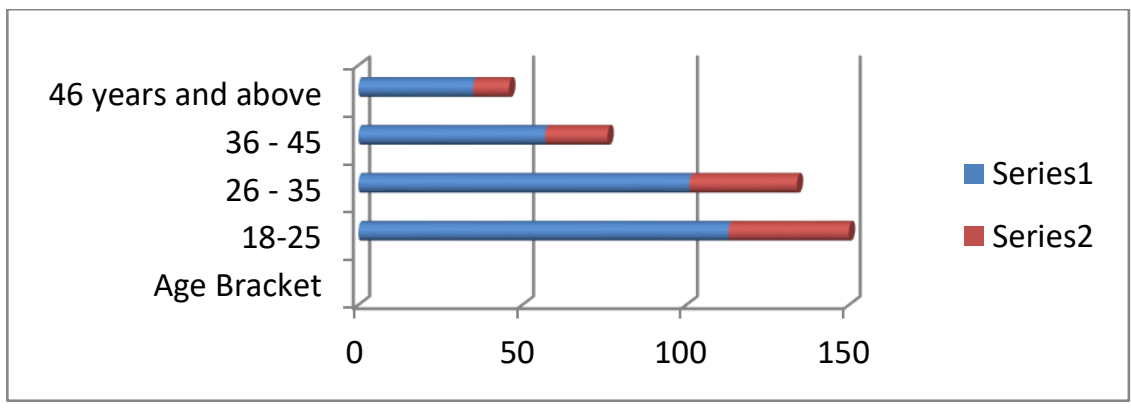

Figure 2. Bar Chart showing age bracket of respondents

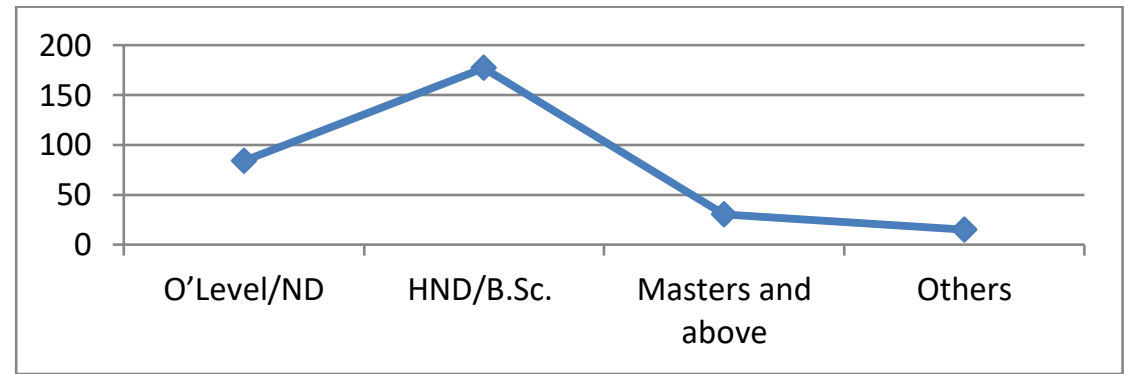

Figure 3. Line Graph showing academic qualification of respondents

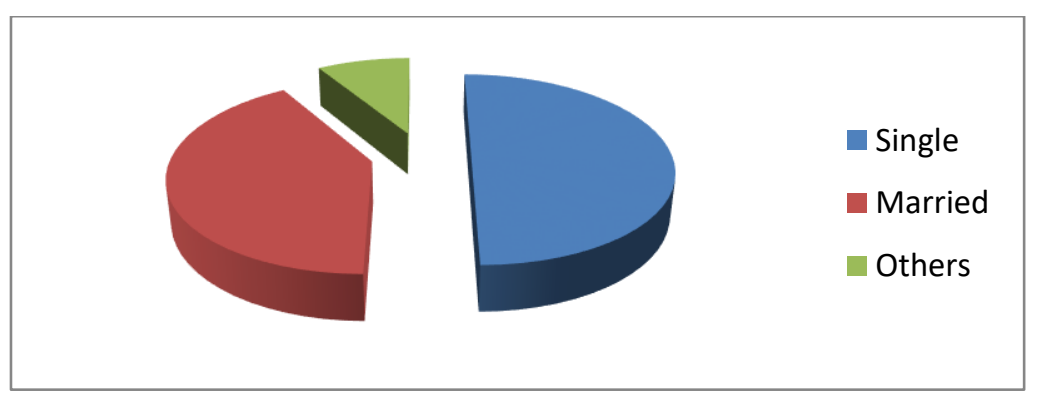

Figure 4. Pie Chart showing academic qualification of respondents

Table 1 showed that there were a total of $117(38 \%)$ male respondents and $189(62 \%)$ female respondents. In terms of their age brackets, the table shows that a total of 113 (37\%) respondents, 101 (33\%) respondents, 57 (19\%) respondents and $35(11 \%)$ respondents were within the ages of $18-25,26-35,36-45$ and 46 years and above, respectively. On their academic qualifications, a total of 85 (27\%) respondents, 177 (58\%) respondents, 30 (10\%) respondents, and $15(5 \%)$ respondents had O'Level/ND, HND/B.Sc., Masters and above as well as other qualifications respectively. Also, data presented in the table show that a total of $153(50 \%)$ respondents were single. 126 (41\%) respondents were married; while 27 (9\%) respondents had other marital statuses.

Table 2. Whether Respondent Had Switched Transport Firms

\begin{tabular}{lll}
\hline Responses & Frequency & Percentage \\
\hline Yes & 171 & 56.00 \\
No & 135 & 44.00 \\
Total & $\mathbf{3 0 6}$ & $\mathbf{1 0 0}$ \\
\hline
\end{tabular}

Source: Field Survey, 2020

This is further presented in figure 5 thus: 


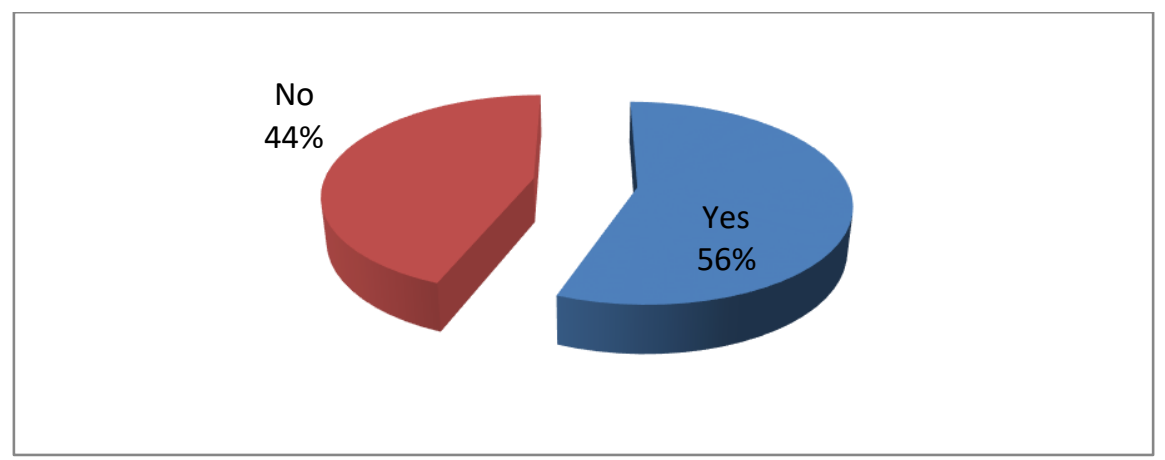

Figure 5. Pie chart on Responses to Switching

Table 2 and figure 5 above show that out of the total number of respondents, 17 (56\%) respondents had switched transport service providers; while 135 (44\%) respondents had not switched transport service providers.

Table 3. Reasons for Loyalty to Transport Service Providers

\begin{tabular}{lll}
\hline Option & Frequency & Percentage \\
\hline Service quality & 89 & 66.00 \\
Affordable prices & 110 & 81.00 \\
Promotional factors & 88 & 65.00 \\
Location of firm & 68 & 50.00 \\
Impressive complaint handling system & 115 & 85.00 \\
Up-to-date resources & 95 & 70.00 \\
\hline
\end{tabular}

Source: Field Survey, 2020

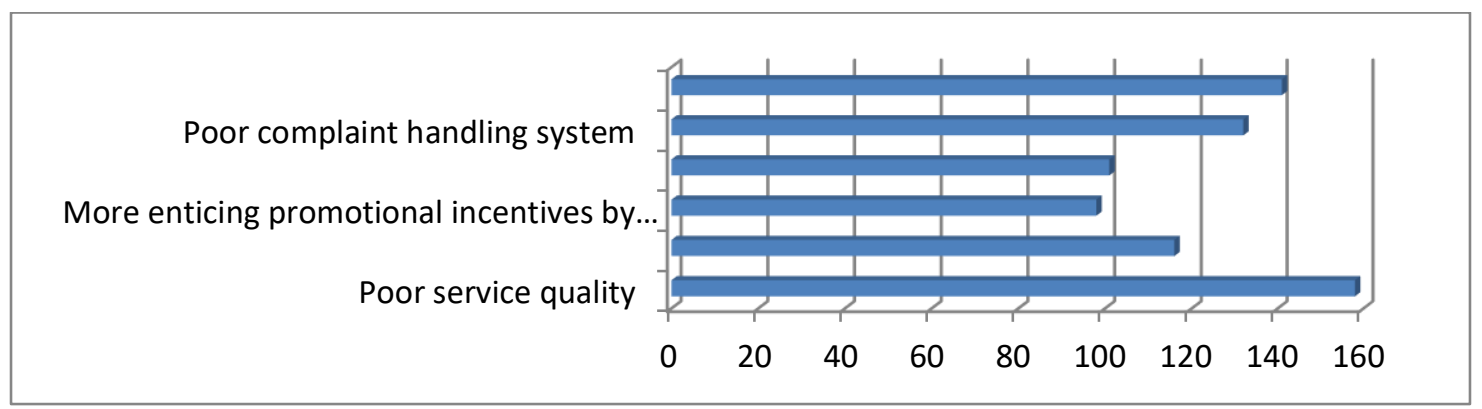

Figure 6. Bar chart showing reasons for loyalty to transport service providers

Information shown in table 3 and figure 6 disclosed that the respondents identified six factors that influence customer loyalty. Thus, out of the 135 respondents that pleaded loyalty, $89(66 \%)$ votes, $110(81 \%), 88(65 \%)$, and $68(50 \%)$, $115(85 \%)$ and $95(70 \%)$ went to Service quality, affordable prices, promotional factors, location of firm, impressive complaint handling system and up-to-date resources, respectively as drivers of customer loyalty.

Table 4. Responses to Questions Relating to Customer Loyalty to the transport firms

\begin{tabular}{lllllll}
\hline Statement & SA & A & UN & D & SD & TOTAL \\
\hline $\begin{array}{l}\text { I was willing to continuously re-patronize my } \\
\text { chosen transporter. }\end{array}$ & 186 & 96 & 30 & 15 & 9 & 336 \\
I had in the past recommended the firm to others & 156 & 69 & 45 & 21 & 15 & 306 \\
\hline
\end{tabular}




\begin{tabular}{lllllll}
\hline Statement & SA & A & UN & D & SD & TOTAL \\
\hline $\begin{array}{l}\text { It was my intention to remain with the firm if the } \\
\text { firm had met my expectations. }\end{array}$ & 174 & 90 & 21 & 12 & 9 & 306 \\
$\begin{array}{l}\text { I was willing to contribute my suggestions to the } \\
\text { firm to put things right. }\end{array}$ & 126 & 117 & 36 & 15 & 12 & 306 \\
$\begin{array}{l}\text { The level of loyalty I intended to keep in the firm } \\
\text { was so strong that I would have been rewarded in } \\
\text { the near future. }\end{array}$ & 90 & 114 & 57 & 15 & 30 & 306 \\
$\begin{array}{l}\text { The trust I had in the firm triggered my repeat } \\
\text { purchase. }\end{array}$ & 183 & 87 & 18 & 12 & 6 & 306 \\
$\begin{array}{l}\text { Initially, I perceived high customer values from the } \\
\text { services of the firm. }\end{array}$ & 177 & 78 & 24 & 15 & 12 & 306 \\
\hline $\begin{array}{l}\text { Total } \\
\text { Average }\end{array}$ & $\mathbf{1 0 9 2}$ & $\mathbf{6 5 1}$ & $\mathbf{2 3 1}$ & $\mathbf{1 0 5}$ & $\mathbf{9 3}$ & $\mathbf{2 1 7 2}$ \\
Percentage & $\mathbf{5 1}$ & $\mathbf{2 0}$ & $\mathbf{3 3}$ & $\mathbf{1 5}$ & $\mathbf{1 2}$ & $\mathbf{3 0 6}$ \\
\hline Source: Fiel Survey & & & $\mathbf{0 5}$ & $\mathbf{0 4}$ & $\mathbf{1 0 0}$ \\
\hline
\end{tabular}

Source: Field Survey, 2020

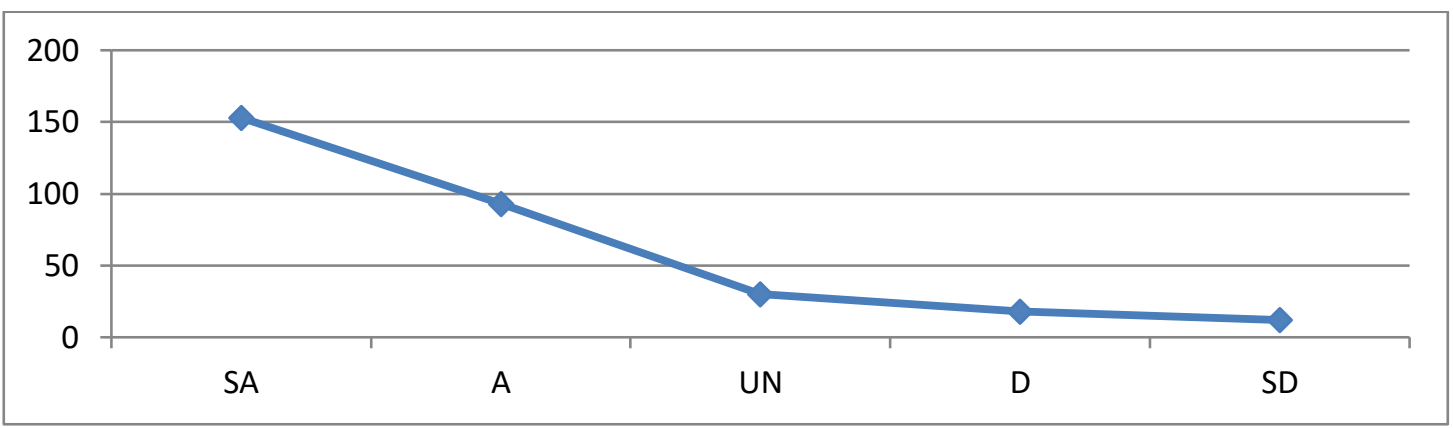

Figure 7. Line graph showing responses to questions relating to customer loyalty

Table 4 and figure 7 showed that on the average, $156(51 \%)$ respondents, 90 (29\%) respondents, 33 (11\%) respondents, $15(5 \%)$ respondents and $12(4 \%)$ respondents strongly agreed, agreed, were indifferent, disagreed and strongly disagreed respectively on the questions relating to the effect of customer loyalty on customer switching behaviour.

Table 5. Responses to Questions Relating to Service Quality

\begin{tabular}{lllllll}
\hline Statement & SA & A & UN & D & SD & TOTAL \\
\hline I expected the services of the firm to be reliable at all times. & 126 & 135 & 24 & 15 & 6 & 306 \\
The assurance I had on the quality of the firm's services reduced reasonably. & 177 & 78 & 24 & 3 & 24 & 306 \\
The tangible facilities of the firm were speedily deteriorating. & 174 & 90 & 33 & 0 & 9 & 306 \\
The firm's staff could no longer respond to my requests timely. & 165 & 96 & 21 & 15 & 9 & 306 \\
Staff became impolite to customers. & 156 & 90 & 33 & 18 & 9 & 306 \\
The firm provided services that were not as promised. & 156 & 69 & 45 & 21 & 15 & 306 \\
\hline Total & $\mathbf{9 5 4}$ & $\mathbf{5 5 8}$ & $\mathbf{1 8 0}$ & $\mathbf{7 2}$ & $\mathbf{7 2}$ & $\mathbf{1 8 3 6}$ \\
Average & $\mathbf{1 5 9}$ & $\mathbf{9 3}$ & $\mathbf{3 0}$ & $\mathbf{1 2}$ & $\mathbf{1 2}$ & $\mathbf{3 0 6}$ \\
Percentage & $\mathbf{5 2}$ & $\mathbf{3 0}$ & $\mathbf{1 0}$ & $\mathbf{0 4}$ & $\mathbf{0 4}$ & $\mathbf{1 0 0}$ \\
\hline Sour
\end{tabular}

Source: Field Survey, 2020 


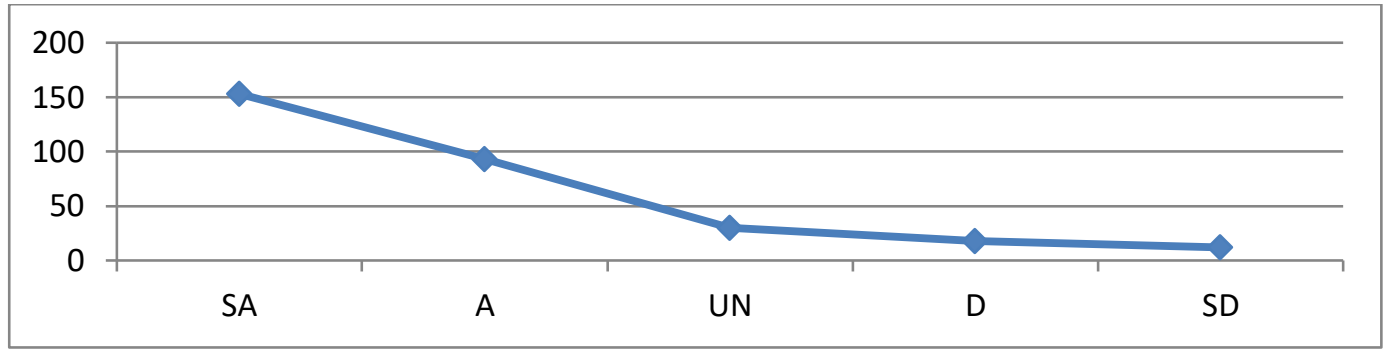

Figure 8. Line graph showing responses to questions relating to service quality

Table 5 and figure 8 showed that on the average, 159 (52\%) respondents, 93 (30\%) respondents, 30 (10\%) respondents, $12(4 \%)$ respondents and $12(4 \%)$ respondents strongly agreed, agreed, were indifferent, disagreed and strongly disagreed respectively on the questions relating to the effect of service quality on customer switching behaviour.

Table 6. Responses to Questions Relating to Price

\begin{tabular}{|c|c|c|c|c|c|c|}
\hline Statement & SA & $\mathbf{A}$ & UN & $\mathbf{D}$ & SD & TOTAL \\
\hline I was no longer getting value for the money I spent. & 147 & 120 & 18 & 15 & 6 & 306 \\
\hline The firm charged high fares. & 156 & 93 & 30 & 3 & 24 & 306 \\
\hline The firm charged exorbitantly on luggage. & 123 & 138 & 24 & 15 & 6 & 306 \\
\hline There was no room for price rebates to loyal customers. & 153 & 114 & 30 & 6 & 3 & 306 \\
\hline The firm charged prices without considering the plight of its customers. & 156 & 90 & 33 & 21 & 6 & 306 \\
\hline Total & 735 & 555 & 135 & 60 & 45 & 1530 \\
\hline Average & 147 & 111 & 27 & 12 & 9 & 306 \\
\hline Percentage & 48 & 36 & 09 & 04 & 03 & 100 \\
\hline
\end{tabular}

Source: Field Survey, 2020

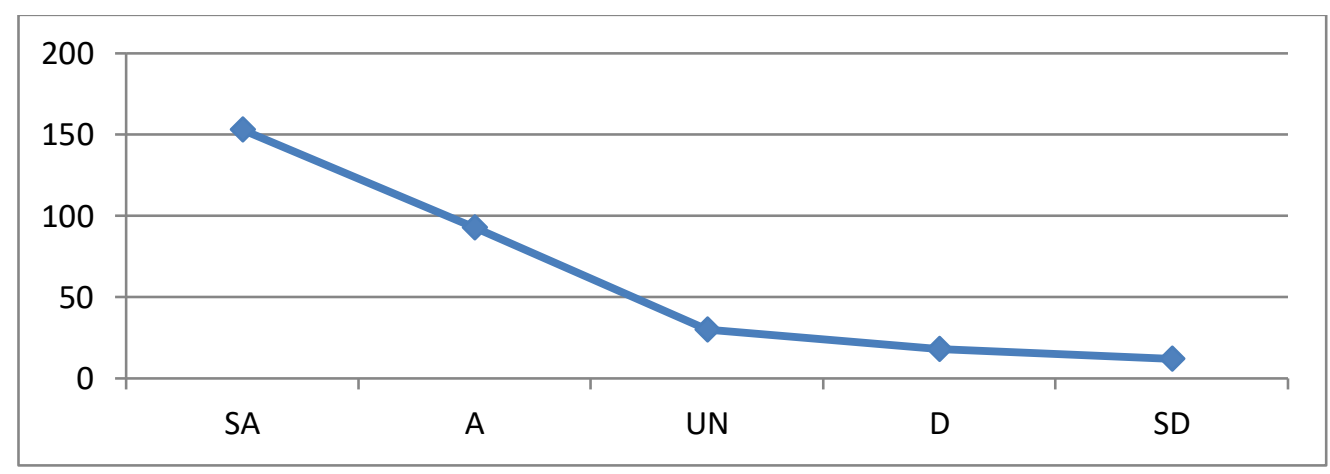

Figure 9. Line graph showing responses to questions relating to price

Table 6 and figure 9 showed that on the average, 147 (48\%) respondents, 111 (36\%) respondents, 27 (9\%) respondents, $12(4 \%)$ respondents and $9(3 \%)$ respondents strongly agreed, agreed, were indifferent, disagreed and strongly disagreed respectively on the questions relating to the effect of price on customer switching behaviour.

Table 7. Responses to Questions Relating to Promotion

\begin{tabular}{lllllll}
\hline Statement & SA & A & UN & D & SD & TOTAL \\
\hline Competing firms' advertisements influenced my & 144 & 99 & 33 & 21 & 9 & 306 \\
\hline
\end{tabular}




\begin{tabular}{lllllll}
\hline Statement & SA & A & UN & D & SD & TOTAL \\
\hline decision to switch transporter. & & & & & & \\
$\begin{array}{l}\text { The word-of-mouth from the Competing firms } \\
\text { customers influenced my decision to switch. }\end{array}$ & 165 & 75 & 36 & 15 & 15 & 306 \\
$\begin{array}{l}\text { The promotional incentives of competing firms } \\
\text { triggered my intention to switch. }\end{array}$ & 153 & 87 & 27 & 24 & 15 & 306 \\
& 150 & 111 & 24 & 12 & 9 & 306 \\
\hline Total & $\mathbf{6 1 2}$ & $\mathbf{3 7 2}$ & $\mathbf{1 2 0}$ & $\mathbf{7 2}$ & $\mathbf{4 8}$ & $\mathbf{1 2 2 4}$ \\
Average & $\mathbf{1 5 3}$ & $\mathbf{9 3}$ & $\mathbf{3 0}$ & $\mathbf{1 8}$ & $\mathbf{1 2}$ & $\mathbf{3 0 6}$ \\
Percentage & $\mathbf{5 0}$ & $\mathbf{3 0}$ & $\mathbf{1 0}$ & $\mathbf{0 6}$ & $\mathbf{0 4}$ & \\
\hline
\end{tabular}

Source: Field Survey, 2020

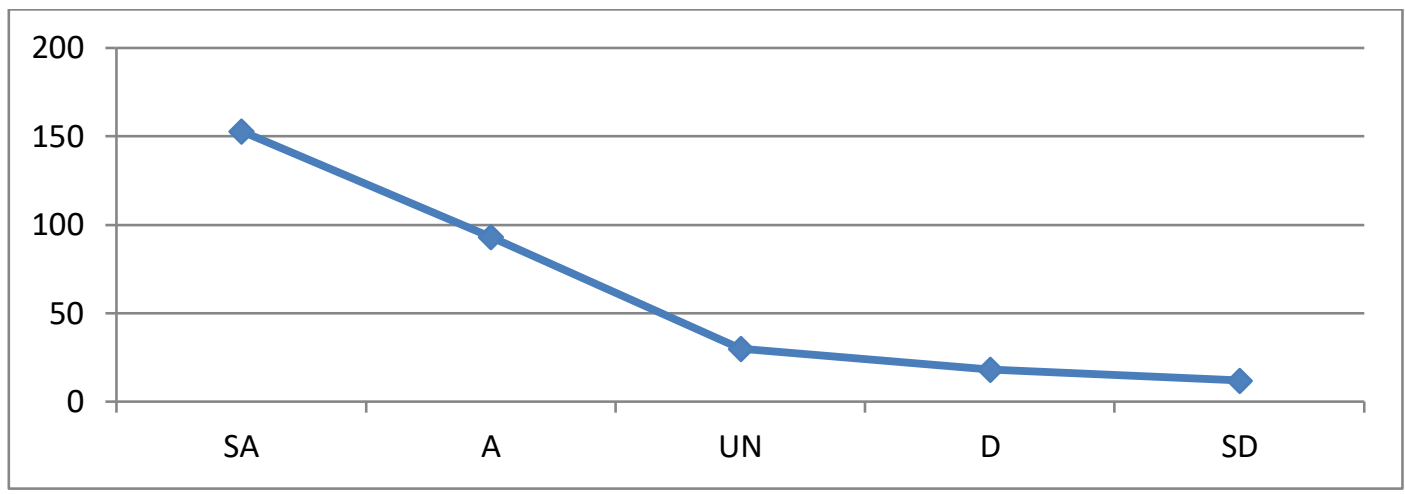

Figure 10. Line graph showing responses to promotion

Table 7 and figure 10 showed that on the average, 153 (50\%) respondents, $93(30 \%)$ respondents, 30 (10\%) respondents, $18(6 \%)$ respondents and $12(4 \%)$ respondents strongly agreed, agreed, were indifferent, disagreed and strongly disagreed respectively on the questions relating to the effect of promotion on customer switching behaviour.

Table 8. Responses to Questions Relating to Location

\begin{tabular}{lllllll}
\hline Statement & SA & A & UN & D & SD & TOTAL \\
\hline $\begin{array}{l}\text { The location of the terminal of my chosen } \\
\text { transporter became inconvenient. }\end{array}$ & 159 & 75 & 36 & 24 & 12 & 306 \\
$\begin{array}{l}\text { I changed my residence and that affected the } \\
\text { proximity of my chosen transporter. }\end{array}$ & 126 & 135 & 24 & 15 & 6 & 306 \\
$\begin{array}{l}\text { Transporters with better offerings were cited closer } \\
\text { to me. }\end{array}$ & 144 & 117 & 30 & 12 & 3 & 306 \\
$\begin{array}{l}\text { It became expensive and time consuming to locate } \\
\text { my preferred transporter. }\end{array}$ & 117 & 126 & 36 & 18 & 9 & 306 \\
\hline Total & $\mathbf{5 4 6}$ & $\mathbf{4 5 3}$ & $\mathbf{1 2 6}$ & $\mathbf{6 9}$ & $\mathbf{3 0}$ & $\mathbf{1 2 2 4}$ \\
Average & $\mathbf{1 2 9}$ & $\mathbf{1 2 6}$ & $\mathbf{3 0}$ & $\mathbf{1 5}$ & $\mathbf{6}$ & $\mathbf{3 0 6}$ \\
Percentage & $\mathbf{4 2}$ & $\mathbf{4 1}$ & $\mathbf{1 0}$ & $\mathbf{5}$ & $\mathbf{2}$ & $\mathbf{1 0 0}$ \\
\hline
\end{tabular}

Source: Field Survey, 2020 


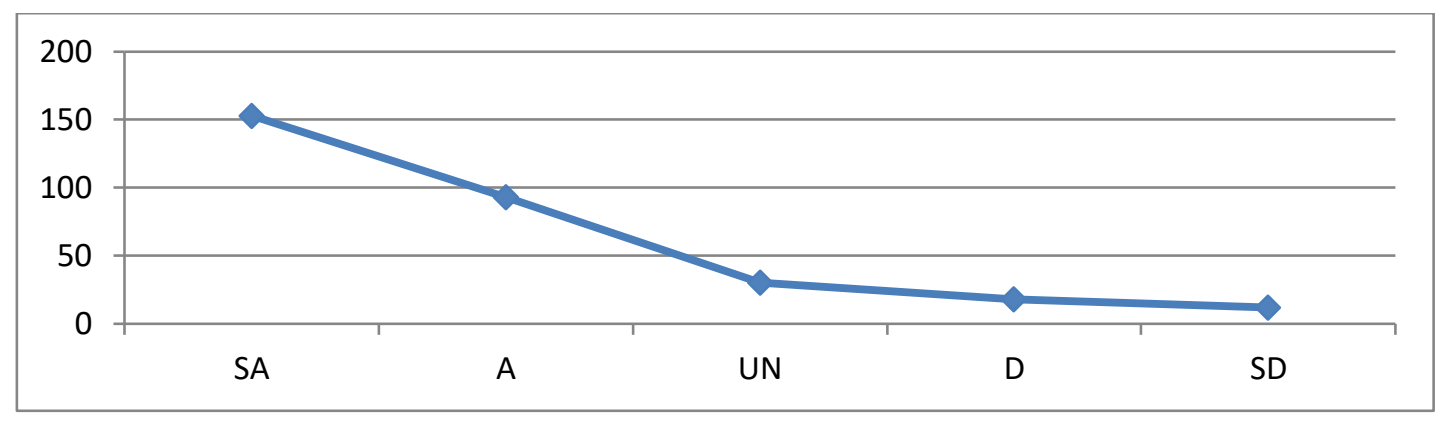

Figure 11: Line graph showing responses to questions relating to location providers

Table 8 and figure 11 showed that on the average, $129(42 \%)$ respondents, $126(41 \%)$ respondents, 30 (10\%) respondents, $15(5 \%)$ respondents and $6(2 \%)$ respondents strongly agreed, agreed, were indifferent, disagreed and strongly disagreed respectively on the questions relating to the effect of location on customer switching behaviour.

\subsection{Test of Hypotheses}

In this section, all the stated hypotheses are tested. Hypotheses one to four were tested using the multiple regression analysis as disclosed in chapter three, while hypothesis seven was tested using the paired samples t-test.

Model Summary ${ }^{\mathrm{b}}$

\begin{tabular}{|l|r|r|r|r|}
\hline Model & \multicolumn{1}{|c|}{$\mathrm{R}$} & R Square & \multicolumn{1}{|c|}{$\begin{array}{c}\text { Adjusted R } \\
\text { Square }\end{array}$} & $\begin{array}{c}\text { Std. Error of the } \\
\text { Estimate }\end{array}$ \\
\hline 1 & $.994^{\mathrm{a}}$ & .989 & .988 & .11444 \\
\hline
\end{tabular}

a. Predictors: (Constant), Customer Switching and Location, Customer Switching and Promotion, Customer Switching and Price, Customer Switching and Service Quality

b. Dependent Variable: Customer Switching Behaviour

\begin{tabular}{|c|c|c|c|c|c|c|}
\hline \multicolumn{7}{|c|}{ ANOVA $^{a}$} \\
\hline & & Sum of Squares & $\mathrm{df}$ & Mean Square & $\mathrm{F}$ & Sig. \\
\hline \multirow{3}{*}{1} & Regression & 342.440 & 4 & \multirow{3}{*}{$\begin{array}{r}85.610 \\
.013\end{array}$} & \multirow[t]{3}{*}{536.891} & \multirow[t]{3}{*}{$.000^{\mathrm{b}}$} \\
\hline & Residual & 3.942 & 301 & & & \\
\hline & Total & 346.382 & 305 & & & \\
\hline
\end{tabular}

a. Dependent Variable: Customer Switching Behaviour

b. Predictors: (Constant), Customer Switching and Location, Customer Switching and Promotion, Customer

Switching and Price, Customer Switching and Service Quality

Coefficients $^{\mathbf{a}}$

\begin{tabular}{|c|c|c|c|c|c|c|}
\hline \multirow{2}{*}{\multicolumn{2}{|c|}{ Model }} & \multicolumn{2}{|c|}{ Unstandardized Coefficients } & \multirow{2}{*}{$\begin{array}{c}\text { Standardized } \\
\text { Coefficients }\end{array}$} & \multirow[t]{2}{*}{$\mathrm{t}$} & \multirow[t]{2}{*}{ Sig. } \\
\hline & & $\mathrm{B}$ & Std. Error & & & \\
\hline \multirow{5}{*}{1} & (Constant) & .029 & .031 & & .939 & .349 \\
\hline & $\begin{array}{l}\text { Customer Switching and Service } \\
\text { Quality }\end{array}$ & .363 & .032 & .354 & 10.245 & .000 \\
\hline & Customer Switching and Price & -.045 & .033 & -.041 & 2.886 & .011 \\
\hline & $\begin{array}{l}\text { Customer Switching and } \\
\text { Promotion }\end{array}$ & .688 & .030 & .696 & 22.963 & .000 \\
\hline & $\begin{array}{l}\text { Customer Switching and } \\
\text { Location }\end{array}$ & -.013 & .025 & -.011 & .580 & 560 \\
\hline
\end{tabular}

a. Dependent Variable: Customer Switching Behaviour 


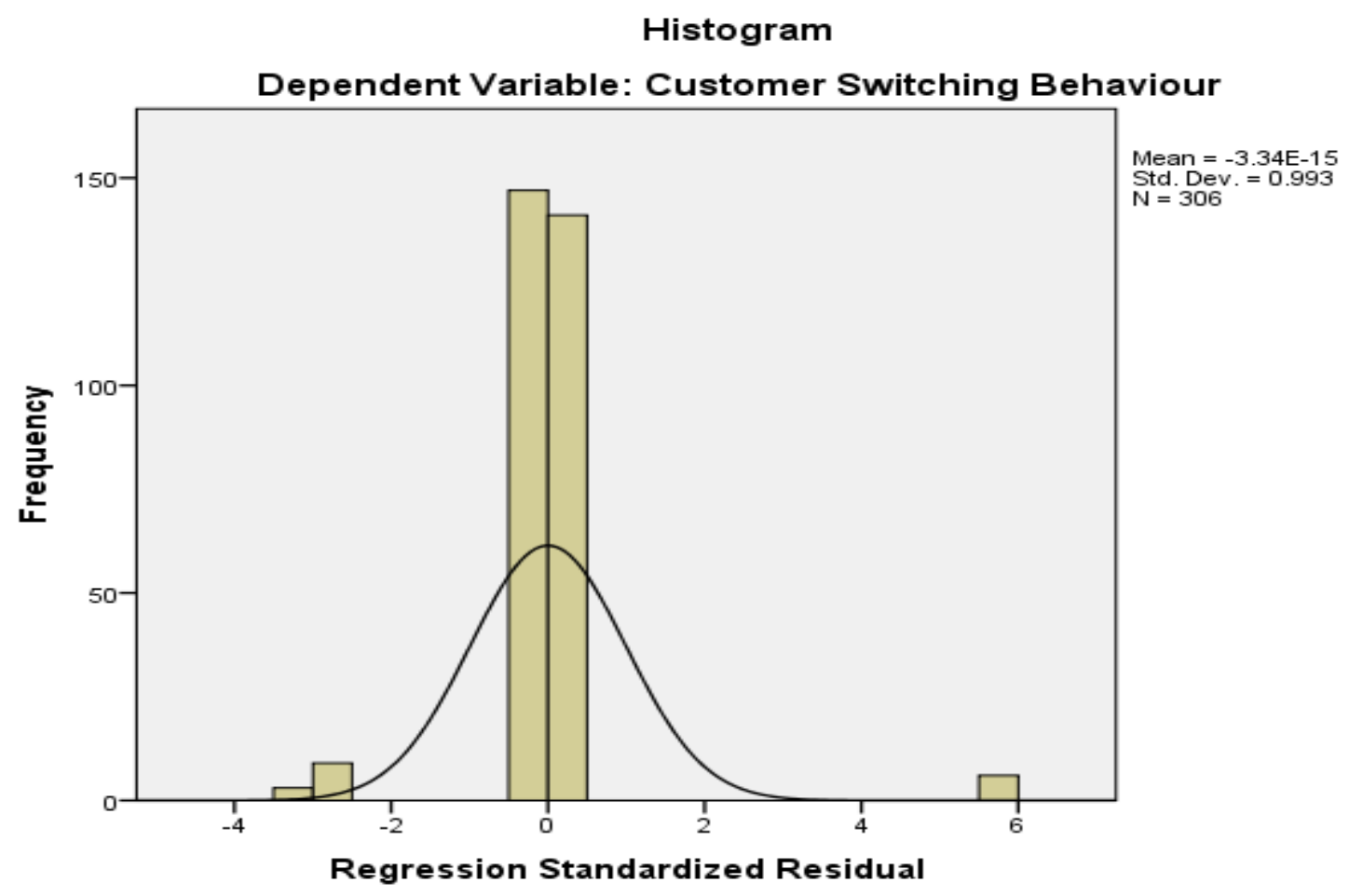

Table 9. Summary of Test of Hypotheses One to Six

\begin{tabular}{lllllll}
\hline S/N & Description & Variable & P-Value & $\begin{array}{l}\text { T-Value } \\
\text { Calculated }\end{array}$ & $\begin{array}{l}\text { T-Value } \\
\text { Critical }\end{array}$ & Decision \\
\hline 1 & Hypothesis One & Service Quality & .000 & 10.245 & 1.960 & Reject Null \\
2 & Hypothesis Two & Price & .011 & 2.886 & 1.960 & Reject Null \\
3 & Hypothesis Three & Promotion & .000 & 22.963 & 1.960 & Reject Null \\
4 & Hypothesis Four & Location & .560 & .580 & 1.960 & Reject Alternative \\
\hline
\end{tabular}

Source: SPSS Output, 2020.

Interpretation: The $\mathrm{R}$ value (.994) shows a very strong, positive and significant relationship exists between the identified drivers and customer switching intention. The adjusted R2 value (.988) reveals that $98.8 \%$ variation in switching intention is predicted by the four variables. Also, the F value (537) and p value $(0.000)$ which are greater than $f$ critical value at 0.05 level of significance (6.39) and less than alpha (0.05) respectively are positive signs of relationship.

The coefficients table show that service quality $(\mathrm{t}=10.245 ; \mathrm{p}=0.000)$, price $(\mathrm{t}=2.886 ; \mathrm{p}=0.011)$ and promotion $(\mathrm{t}=22.963 ; \mathrm{p}=0.000)$ are significant predictors of customer switching behaviour. This is because their $\mathrm{p}$-values are less than alpha (0.05) and their $\mathrm{t}$-values greater than $\mathrm{t}$-critical $(1.960)$. Location $(\mathrm{t}=.584 ; \mathrm{p}=0.560)$ is not a significant predictor of switching intention since the $\mathrm{p}$-value is greater than alpha and the t-value less than t-critical.

Decision: Since F calculated (537) is greater than F critical (6.39) and the p value (0.000) is less than alpha (0.05), we therefore reject the Null hypotheses one, two and three and accept the alternative hypotheses which states that there is positive relationship between (service quality, price and promotion) and customer switching intention in the road transport industry in South East Nigeria. Again, we reject the alternative hypothesis four and accept the null hypothesis. This implies that there is no significant and positive relationship between location and customer switching intention. 


\section{Summary, conclusion and recommendations}

\subsection{Summary}

Based on the statistical analyses, the major findings indicated that:

(1) Service quality is a significant predictor of customer switching behaviour in the road transport sector. This implies that road transport firms with unreliable services, unstable service assurance, degraded tangibles, not responsive to customers requests, impolite staff will experience customer drop. $82 \%$ positive votes were received on this factor.

(2) Much unlike many extant studies, our findings also show that price significantly predicts customer switching behaviour with $84 \%$ affirmative votes. This implies that firms that offer values not commensurate with price charged, very high fare, high luggage charges, poor or no rebates and inconsiderate charges will experience customer switching.

(3) Promotion is a significant predictor of customer switching behaviour with $80 \%$ positive votes. Thus firms with poor advertisement, poor word-of mouth and poor promotional incentives will experience customer churn.

(4) Location has weak and insignificant influence on customer switching behaviour towards road transport services. This implies that customers will be willing to patronize firms that offer expected value to them irrespective of the location of company terminals.

\subsection{Conclusion}

A few studies have concentrated on the Nigerian road transport industry with a view to re-positioning it for greater impact on the economy, given its position in the transport sector. This study, unlike others has extended literature and empirical researches on the switching behaviour of customers in the road transport industry. A good understanding of the factors that drive customer switching is needed to compete effectively in the present Nigerian road transport industry. This is because customers are now more informed, educated, seeking for value for their money, ICT complaint and relying more on e-word-of-mouth for loyalty and or switching decisions. Competition has become increasingly intense resulting in customer switching behaviour amongst customers who desire the best in terms of convenience, safety, customer friendly, timely and affordable services. It seems, however that the operators are yet unaware of the key factors that trigger such a magnitude of switching actions and their attendant marketing implications. There is urgent need to call the attention of the road transport services marketers to the marketing implication of customer switching intentions on their marketing performance. The providers would also need research based evidences of customers' views of the antecedents or drivers of switching behaviour in the road transport industry. This study used an adapted version of the Keveney (1995) and Onyeagwara and Agu (2017) models of customer switching behaviour to explore the switching behaviour of customers of road transport firm in the SouthEaast.

\subsection{Recommendations}

Based on the findings of this study, the following recommendations are hereby made:

(1) Given the sophisticated nature of the present demands of road transport customers, road transport service providers are expected to strive to reduce service switching and enthrone customer loyalty. A focus on the proven drivers of loyalty such as effective complaint resolution system, affordable charges, up-to-date facilities, good service quality and periodic promotional incentives is recommended. Customer loyalty guarantees continuous repatronage, recommendation of firm by customers, profitable customer suggestions, improved customer trust and customer word-of-mouth.

(2) Road transport firms are expected to be service quality conscious as this will reduce customer switching. Monitoring the service quality using the RATER model is recommended. Here, firms are required to be reliable, uphold service assurance, minds their tangibles, be empathic and responsive.

(3) Since price emerged as an influencing factor in this study, effective and competitive price management is suggested for the road transport managers. This expects that firms offer values that are commensurate with price charged, fair prices, considerate luggage charges and periodic rebates as these will reduce customer switching. 
(4) Road transport firms are encouraged to engage in regular cost-effective promotion of their services. This improves the image of the firms and ego of those patronizing them. Periodic advertisement, promotional incentives, publicity and good public relations are among strong promotion tools firms can adopt.

\section{References}

Ackerberg, D. A. (2003). Advertising, learning and consumer choice in experience good markets: An empirical examination. International Economic Review, 44(3), 1007-1040.

Agbonifoh, B.A, Ogwo, E.O, Nnolim, D. A. \& Nkamnebe, A. D. (2007) Marketing in Nigeria, concepts, principles and decisions. Aba: Afritowers Limited.

Agu, G. A. (2015). Customer complaint behaviour in the service industry: a study of the customers of the organized road transport firms in Imo State. Ph.D. Thesis, Abia State University, Nigeria.

Agu, G. A., Samuel, G. E., \& Ikenna, M. H. (2019). Impact of customer touch point management on banks' performance. Archives of Business Research, 7(3SP), 66-73.

Agu, G.A, Madumere, H.I \& Uche, D.B (2016). Determinants of passengers' preference for long distance shuttle services in Nigeria. IJBFMR, 5(4).

Ajzen, Icek. (1991). The theory of planned behavior. Organizational Behavior and Human Decision Processes, 50, 179-211.

Baohong S., Scott, A. N. and Kannan, S. (2003) Measuring the Impact of Promotions on Brand Switching When Consumers Are Forward Looking. Journal of Marketing Research, Vol. 40, No. 4 (Nov., 2003), pp. 389-405

Biggs P, and Kelly T. (2006) Broadband pricing strategies. Info, 2006, 8(6):3-14

Bitner, M. J \& Hubbert, A. R. (1994). Encounter satisfaction versus overall satisfaction versus quality, in Rust, R. T. and Oliver, R. L. (Eds), Service Quality: New Direction in Theory and Practical. Sage: London.

Boote (1998). Towards a comprehensive taxonomy and model of consumer complaining behaviour. Journal of Consumer Satisfaction, Dissatisfaction and Complaining Behaviour, 11. 141-149.

Burnham, T.A., Frels, J.K.,\& Mahajan, V. (2003). Consumer switching costs: A typology, antecedents and consequences. Journal of the Academy of Marketing Science, 2(3), 1-13.

Chakrabortty, R. K., Hossain, M. M., Azad, M. F. H., \& Islam, M. J. (2013). Analysing the effects of sales promotion and advertising on consumer's purchase behaviour. World Journal of Social Sciences, 3(4), 183 - 194.

Chu, K. M. (2009). The construction model of customer trust, perceived value and customer loyalty. The Journal of American Academy of Business, Cambridge, 14 (2), 98-103.

Cronin, J. J., \& Taylor, S. A. (1994). SERVPERF versus SERVQUAL: Reconciling performance-based and perceptions-minus-expectations measurement of service quality. Journal of Marketing, 58(1), 125-131.

Deighton, J., Henderson, C. M., \& Neslin, S. A. (1994). The effects of advertising on brand switching and repeat purchasing. Journal of Marketing Research, 31(1), 28-43.

Grewal D, Roggeveen A L, Compeau L D, Levy M. (2011) Evolving pricing practices: The role of new business models. Journal of Product and Brand Management, 2011, 20(7):510-513

Karine E M, Frank L, Laine K. (2004) Effect of price on the diffusion of cellular subscriptions in Finland. Journal of Product and Brand Management, 2004, 13(3):192-199

Keaveney, S. M. (1995). Customer switching behavior in service industries: an exploratory study. Journal of Marketing, 59 (2), 71-82.

Kim, J. H., \& Hyun, Y. J. (2011). A model to investigate the influence of marketing-mix efforts and corporate image on brand equity in the IT software sector. Industrial Marketing Management, 40(6), 424-438. 
Kollmann T. (2000) The price/acceptance function: perspectives of a pricing policy in European telecommunication markets. European Journal of Innovation Management, 2000, 3(1):7-15

Kumar, A. \& Dash, M. K. (2015). E-service quality dimensions' effect on customers' willingness to buy: structural equation modeling approach. Int. J. Services and Operations Management, 22 (3), 287 - 303.

Kumaradeepan, V. (2012) The Impact Of Service Quality On Customer Swicthing In Telecommunication Industry Jaffna District, Srilanka. Zenith International Journal of Business Economics \& Management Research Vol.2 Issue 5, May 2012, ISSN 22498826 Online available at http://zenithresearch.org.in/

Liang, C. J. \& Wang, W. H. (2008). Do loyal and more involved customers reciprocate retailer's relationship efforts? Journal of Services Research 8(1), 63-90.

Liu, C. (2015). The impact on switching intention of e-trading systems for the securities industry. Global Journal of Business Research, 9 (1), 75-88.

Lovelock, C, Wright, L, 1999, Principles of Service Marketing and Management, Prentice-Hall, Englewood Cliffs, $\mathrm{NJ}$

Madden, T. J., Ellen, P. S., \& Ajzen, I. (1992). A comparison of the theory of planned behavior and the theory of reasoned action. Personality and Social Psychology Bulletin, 18 (1), 3-9.

Mouri, N. (2005). A customer-based assessment of alliance performance: an examination of customer value, satisfaction and post-purchase behaviour. University of Central Florida, Available on: http://proquest.umi.com/pqdweb?did=10147471\&Fmt=2\&clientld=46934\&ROT=309\&VName=PQD.

Murtiasih, S., Sucherly, \& Siringoringo, H. (2013). How word of mouth influence brand equity for automotive products in Indonesia. Procedia - Social and Behavioural Sciences, 81(6),40 - 44.

Nagar, K. (2009). Evaluating the effect of consumer sales promotions on brand loyaland brand switching segments. The Journal of Business Perspective, 13(4), 35-48.

Nyarko, I. K. (2015) Evaluation Of Factors Influencing Switching Behaviour By Ghana Commercial Bank Customers. British Journal of Marketing Studies, Vol.3, No.8, pp.35-46, December.

Ogwo, E. O. \& Agu, G. A. (2016). Transport infrastructure, manufacturing sector performance and the growth of gross domestic product in Nigeria (1999 - 2011). Journal of Business and African Economy, 2 (1), 236-248.

Okpara, G.S. (2012), Contemporary Marketing: Topical and Tropicalised, Owerri: Avan Global Publications.

Onyeagwara, C. A., Agu, G. A., \& Aja, E. E. (2019). Predictors Of Consumers' Choice Of Buying Outlets In Imo And Abia States, Nigeria. Archives of Business Research, 7(SP), 34-48.

Pradhan, D., Duraipandiana, I., \&Sethi, D. (2014). Celebrity endorsement: How celebrity-brand-user personality congruence affects brand attitude and purchase intention. Journal of Marketing Communications, 1-18, DOI: $10.1080 / 13527266.2014 .914561$.

Rajkumar, R.\& Chaarlas, I. J. (2011). Brand switching in cellular phones service industry because of bill-related issues faced by clients, International Journal of Electronic Marketing and Retailing, 1 (5), 213-225.rsSaunde

Reichheld, F. F. \& Sasser, W. E. Jr (1990). Zero defections: Quality comes to service. Harvard Business Review, (September-October), 105-111.

Rust, R., \& Zahorik, A. (1993). Customer satisfaction, customer retention and market share. Journal of Retailing,69(2), 193-215.

Sahoo, D. K. (2018) Service Quality and Switching Behavior of Customers: An Empirical Investigation on SBI Customers of Cuttack District of Odisha. IOSR Journal of Humanities and Social Science (IOSR-JHSS) eISSN: 2279-0837, p-ISSN: 2279-0845 PP 01-08 www.iosrjournals.org

Serkan, A. \& Ozer, G. (2005).The analysis of antecedents of customer loyalty in the Turkish mobile telecommunication market. European Journal of Marketing, 39 (7/8), 910-925.

Shah, M. A. R., Husnain, M. \& Zubairshah, A. (2018). Factors affecting brand switching behavior in telecommunication industry of Pakistan: a qualitative investigation. American Journal of Industrial and Business Management, 8, 359-372 http://www.scirp.org/journal/ajibm 
Srivastava, A., \& Dr. Bisen, V. (2014). Consumers buying and switching behaviour due to advertising: A study on shampoo brands. Journal of Research in Management and Technology, 3(3), 14-21.

Stewart, K. (1994). Customer Exit: Loyal Issues in Retail Banking. Irish Marketing Review, 7, 45-53.

Vilcassim, N. J., \&. Jain, C. D. (1991). Modeling purchase-timing and brand-switching behaviour incorporating explanatory variables and unobserved heterogeneity. Journal of Marketing Research, 28(1), 29-41.

Xavier P. and Ypsilanti D. (2008) Switching costs and consumer behaviour: Implications for telecommunications regulation. Info, 2008, 10(4):13-29 